\title{
The Experience of Absorption of New Immigrant Adolescents in the Digital Age, as Perceived by Mentors Who Work With Them From a Social-Emotional Point of View
}

\author{
Gila Cohen Zilka \\ Correspondence: Bar-Ilan University; Achva Academic College, Israel \\ Received: May 16, 2021 Accepted: June 23, 2021 Online Published: July 12, 2021 \\ doi:10.5539/res.v13n3p31 URL: https://doi.org/10.5539/res.v13n3p31
}

\begin{abstract}
Immigration of adolescents involves multiple, many-faceted changes. This study examined the experience of absorption of adolescents in Israel, in the digital age, through the eyes of mentors who work with them, from the mentors' social-emotional perspective of themselves and of their students. In this mixed-method study, 122 mentors completed questionnaires with closed and open-ended questions, and wrote extensively about their difficulties. The findings show that most mentors $(66 \%)$ worked hard to make their students part of the social fabric. Some of the mentors $(34 \%)$ encountered problems resulting from misunderstandings and poor communication because of language difficulties and lack of control over pragmatic aspects in a sociocultural context. They strove to raise social awareness in the adolescents through observation, and to provide tools for reading and responding to behaviors, all the while encouraging social involvement. Mentors thought that digital environments helped them and the adolescents in their coping. Thanks to digital environments, especially smartphones, adolescents were able to blend into their new environment. Translation, databases, numerous applications, and groups on social networks respond to their needs and help with difficulties they encounter in real time, creating a sense of social connection and belonging.
\end{abstract}

Keywords: immigrant, information and communication technology (ICT), equal opportunity, belonging, alienation

\section{Introduction}

Migration is a process of transition from one culture to another. This process usually requires many adjustments at multiple levels to deal with physiological, emotional, mental, and social changes, and involves disconnecting from the socialization process in the country of origin. The aim of the present study was to examine the experience of absorption of new immigrant adolescents in the digital age, through the eyes of mentors working with them, from the mentors' social-emotional perspective of themselves and their charges, with respect to assistance to adolescents in social and emotional aspects; belonging vs alienation; integrating digital environments in the work of the mentors with new immigrant youths; and the social-emotional aspects of the mentors' work. Comparison of the adaptation of immigrants in the age of developed digital environments with that of immigrants in previous decades (Choi, 2008; Maldonado-Molina et.al., 2011; Rossiter \& Rossiter, 2009; Spallek et.al., 2010; Yearwood et.al., 2007; Zilka, 2019a, 2019b) shows that immigrants feel that the transition from the country of origin to the new country is not a sharp one, as it allows contact with those who remained in the country of origin. Immigrant youths view digital environments as a door to a global world, open and full of possibilities and information, compensating for the shortcomings and difficulties they encounter in the new country and for the physical distance between them and their friends and loved ones who remained abroad. Both in hard times and good ones, they have someone with whom to share experiences, in their native language. They find that communication alleviates feelings of longing, enabling intimate discourse, sharing of emotions, releasing anger, and soothing frustration (Moore \& McElroy, 2012; Zilka, 2017, 2019a, 2020b).

\section{Immigrant Adolescents}

Many immigrants encounter problems such as language barriers, choice of area of residence, housing issues, economic hardship, and difficulties in the process of adapting to the new society and culture. Often there is tension between the cultural views of the immigrants and their daily experiences in the new society, and such tensions aggravate the plight of immigrant children (Choi, 2008; Maldonado-Molina et.al.,2011; Rossiter \& Rossiter, 2009; Spallek et.al., 2010; Yearwood et.al., 2007). The decision to emigrate from one country to another is usually made by parents and not by their children.

The process of absorption in a new country places the immigrants in a situation of bi-culturalism and bilingualism. 
Immigrant adolescents are required to reinvent their identity, while non-immigrant adolescents at this time consolidate their identity. Lack of command of the language is revealed as the most prominent difficulty in the functioning of new immigrants. Another difficulty is the lack of understanding of pragmatic aspects in their socio-cultural context, such as irony, humor, rhetorical questions, and more. Socio-cultural mediation in oral and written discourse is important. With progress in language acquisition, immigrants learn the patterns of discourse and internalize the pragmatic-rhetorical aspects of the language (Budría et.al., 2018; McCarty, 2018; Nesterko et.al., 2018; Puigdevall et.al., 2018; Repke \& Benet-Martínez, 2018; Sevinç \& Dewaele, 2018; Spörlein \& Kristen, 2018; Zilka, 2019b; Zorlu \& Hartog, 2018).

The period of adolescence is characterized by a process of identity formation and coping with changes, including physiological, emotional, mental, and social changes. Studies (Birch \& Ladd, 1997, 1998; Romi et.al., 2007; Zilka, $2015,2017,2020 \mathrm{~b}$ ) indicate that the wellbeing of adolescents may suffer as a result of immigration. Their academic ability, the process of acquiring skills, their sense of self-worth, and social connectedness may all be impaired. These states can cause dysfunction in various areas, and even social deviance. Therefore, the mentors and teachers who work with the youths must provide an environment that elicits feelings of belonging, protection, growth, ability, meaningful interactions, positive experiences, and successes, and enables feelings of self-worth, being needed, and contribution to the environment (Birch \& Ladd, 1997, 1998; Romi et.al., 2007; Zilka, 2015, 2017).

\section{Mentors for New Immigrant Youth}

Daloz (1987) noted that the role of the mentor is holistic: the mentor must be involved in the students' life and pay attention to it, conduct a dialogue with the students about their problems, help students formulate their wishes, and build a work plan that suits the students' needs and interests. Such a program should address the student's emotional and social difficulties and boost their strengths. The mentor's role is to help the students track their progress toward achieving academic, social, and emotional goals. Daluz characterized the ideal mentor as one who enables a process in which the mentor helps the students become aware of their problems and wishes, motivates the students, and helps them deal with difficulties and fears. Such process should lead to a transformation of the students, and affect their identity and personality. The mentors should construct their ways of working with the adolescents taking into account several elements (Daloz, 1987; Kagan, 1982; Winnicott, 1965; Zilka, 2017) building trust between the mentor and the student, identifying goals, maintaining dialogue, and creating a protected space that gives the student a sense of security.

\section{Social-Emotional Learning (SEL)}

The main goals of the socio-emotional approach are cultivating a sense of resilience, empathy, self-efficacy, growth mindset and decision-making ability, self-awareness, self-management, social awareness, management of interactions, and accepting responsibility. The mentors who participated in this study were trained to pay attention to social-emotional aspects in their work, both in relation to themselves and to their students. Researchers (Husaj, 2016; Zilka, 2015, 2017) argued that using a methods based on SEL involves teaching, promoting, and applying social and emotional skills in ways that are developmentally and culturally adapted to the students as well as to the mentors themselves. Emotional and social difficulties affect the students' wellbeing, their academic achievements, and their general mood. Teaching with the SEL method involves five sets of interconnected skills: self-awareness, self-management, social awareness, interaction management, and acceptance of responsibility.

Self-awareness refers to awareness of emotions, feelings, desires, needs, actions, behaviors, etc.

Self-management refers to a set of traits for regulating, assessing, understanding, and managing a person's feelings and beliefs toward self and others, and turning the information into useful knowledge that guides and directs the person's thinking and actions.

Social awareness refers to awareness, mindfulness of one's own feelings, and the feelings of others.

Interaction management refers to attention to the nature of interactions with others: nurturing, advancing, harming, etc.; making eye contact, using encouraging or distancing words, etc.; awareness of emotions, managing emotions and empathy, because the other's emotions greatly affect one's relationship with oneself and with others.

Accepting responsibility concerns a decision to change and the implementation of the decision to change the aspects of behavior that the person finds inappropriate. Proposing different options for dealing with various situations, behaviors, etc., in a different way from the one followed so far. After selecting a preferred option, the individual builds milestones for future actions that are likely to lead to a change in behavior (Beauchamp, 2015; Farr, 2010; Liu, 2015; Nooreiny, 2007; Shoffner, 2009; Whitton et.al., 2004). Researchers (Husaj, 2016; Zilka, 2015, 2017, 2020a) have assumed that the following social and emotional skills are acquired skills that can be learned and practiced, among others: self-esteem, self-awareness, emotion management, assertiveness, self-fulfillment, motivation, empathy, impulse control, self-discipline, perseverance, resilience, relationship management, social responsibility, adaptation, problem solving, stress management, stress management, and delay of gratification. 
The mentors worked with the adolescents in school and accompanied them to after-school complementary frameworks, at the end of their school day. In these settings children received hot meals, notebooks and stationery, and those in need also receives clothes and food to take home, or a sandwich for school.

\section{Integrating Digital Environments in Working With New Immigrant Youths}

Researchers (Choi, 2012; Foti \& Mendez, 2014; Hanafi \& Samsudin, 2012; Rossing et.al., 2012; Schugar et.al., 2013; Warschauer, 2011; Zilka, 2018a, 2018b, 2019b) found that the integration of digital environments in the lives of adolescents leads to increased motivation, social and educational engagement, and makes possible attractive and diverse learning environments. It helps illustrate the study content and makes it accessible through images, animation, simulations, videos, etc. on the Internet, making it available to students. Digital environments are becoming increasingly available, with expanding functionality, a wide range of applications, and access at any time, from anywhere (Cohen et al., 2015; Dahlstrom, 2015; Zilka, 2019b).

Researchers (Jan et.al., 2016; Johnson et.al., 2011; Zilka, 2019a) found that integration of digital environments in the learning process makes it possible to make learning part of the learners' daily activities, foster student engagement, collaboration, and more. It also creates equal opportunities for students with special needs, accessibility problems, etc. (Gikas \& Grant, 2013; Zilka, 2019a). Researchers used the concept of m-learning, defined as a learning activity carried out in digital environments (Jan et.al., 2016; Johnson et.al., 2011; Sung et.al., 2016).

The aim of the present study was to examine the experience of absorption of new immigrant adolescents in the digital age from the vantage point of mentors working with them, and from the mentors' social-emotional perspective of themselves and of their students, as they assist students with the social and emotional aspects of their integration. The study examined belonging vs alienation, integrating digital environments in the work with new immigrant adolescents, and the social-emotional aspects of the mentors' work.

\section{Method}

This is a mixed-method study: 122 mentors completed questionnaires with closed and open-ended questions. In addition, they were asked to share in writing their difficulties in working with new immigrant adolescents.

\section{Sample}

One hundred twenty two adult mentors aged 20 to 32, who had at least one year of experience working with immigrant youths, participated in the study. The mentors worked with Israeli immigrant adolescents between the ages of 12 and 18, who had been in the country for less than two years.

The mentors worked with the adolescents in the school, and at the end of their school day accompanied them directly to complementary frameworks.

\section{Research Tools}

The quantitative questions, at the beginning of the questionnaire, were followed by open-ended questions. The questionnaire was based on Zilka (2019a, 2019b).

The following closed questions (statements) appeared in the questionnaire: I am able to help students deal with their social problems; I always make sure to know why my students are absent and ask about their wellbeing after they return to class; I am able to have conversations with students that enhance the atmosphere and relationships in the classroom; I am confident in my ability to conduct meaningful personal conversations with my students; I often find opportunities for personal conversations with my students and take an interest in them; I really care about what happens in school; My responses to students' social problems are effective and achieve their purpose; I see the importance of having personal conversations with my students; I make sure to have personal conversations with my students; I feel I have sufficient time and space for conducting a dialogue with my students; I have tools for conducting meaningful personal conversations with my students.

The open questions were:

Can you speak your students' mother tongue? If so, does it help you in working with them? How? If not, how do you communicate with them ? Do you feel that you are helping your students in their studies? Do you feel that you are helping your students socially? Do you feel that you are helping your students emotionally? Do you think that you succeed in making it easier for your students to handle the difficulties they have as new immigrants? How many hours a week do you work with each student? Do you teach them to use a computer / digital environment? Do you use a computer / digital environment to help them? Explain how do you think the computer / smartphone / digital environments help them handle their problems? 


\section{Data Analysis}

Quantitative analysis. All data were entered into the SPSS software, where the statistical analyses were performed.

Qualitative analysis. Discourse analysis was performed on the collected data, based on the approach of Adler and Adler (2008), Atkinson and Delamont (2006), and Hammersley (2008). The process was iterative and continuous, and in the end, data were consolidated into particular issues, showing sensitivity to context and its place in the construction of reality.

\section{Findings}

The findings are presented in the following order: first, the quantitative findings, then the qualitative findings that emerged from the mentors' answers.

A. Perception of fulfilling their role as mentors of new immigrant youth

Table 1. Quantitative data obtained from closed questions (statements)

Estimation of prevalence was performed using a 5-point ordinal scale, $1=$ disagree, $2=$ disagree to a small extent, $3=$ agree to a moderate extent, $4=$ agree, $5=$ agree to a large extent.

\begin{tabular}{|c|c|c|c|c|c|c|}
\hline & Average & $\begin{array}{l}\text { Prevalence } \\
\text { of } 1\end{array}$ & $\begin{array}{l}\text { Prevalence } \\
\text { of } 2\end{array}$ & $\begin{array}{l}\text { Prevalence } \\
\text { of } 3\end{array}$ & $\begin{array}{l}\text { Prevalence } \\
\text { of } 4\end{array}$ & $\begin{array}{l}\text { Prevalence } \\
\text { of } 5\end{array}$ \\
\hline $\begin{array}{l}\text { I am able to help my students deal } \\
\text { with their social problems }\end{array}$ & 3.9 & & 4 & 38 & 40 & 40 \\
\hline $\begin{array}{l}\text { I always make sure to know why a } \\
\text { student is missing and take interest } \\
\text { in his well-being when he returns to } \\
\text { class }\end{array}$ & 4.3 & & 4 & 12 & 50 & 56 \\
\hline $\begin{array}{l}\text { I am able to have conversations with } \\
\text { my students that enhance the } \\
\text { atmosphere and the relationship in } \\
\text { the classroom }\end{array}$ & 4.3 & & 2 & 10 & 50 & 60 \\
\hline $\begin{array}{l}\text { I am confident in my abilities to } \\
\text { have a meaningful personal } \\
\text { conversation with my students }\end{array}$ & 4.3 & & 4 & 18 & 28 & 72 \\
\hline $\begin{array}{l}\text { I often find opportunities for } \\
\text { personal conversations with my } \\
\text { students and take an interest in them }\end{array}$ & 4.2 & & 4 & 20 & 44 & 56 \\
\hline I really care what happens at school & 4.2 & & 4 & 16 & 54 & 48 \\
\hline $\begin{array}{l}\text { My responses to the social problems } \\
\text { of my students are effective and } \\
\text { achieve their purpose }\end{array}$ & 3.7 & & 6 & 34 & 61 & 20 \\
\hline $\begin{array}{l}\text { I see the importance of having } \\
\text { personal conversations with my } \\
\text { students }\end{array}$ & 4.7 & & 2 & 2 & 26 & 90 \\
\hline $\begin{array}{l}\text { I make sure to have personal } \\
\text { conversations with my students }\end{array}$ & 4.3 & & 2 & 16 & 38 & 66 \\
\hline $\begin{array}{l}\text { I feel I have time and space for } \\
\text { dialogue with my students }\end{array}$ & 4.1 & 2 & 6 & 26 & 32 & 56 \\
\hline $\begin{array}{l}\text { I have tools for conducting } \\
\text { meaningful personal conversations } \\
\text { with my students }\end{array}$ & 2.5 & 28 & 30 & 38 & 16 & 12 \\
\hline
\end{tabular}

B. The open questions

1. Can you speak your student's mother tongue?

Yes - 36; No - 66; Somewhat - 20. The findings showed that 36 mentors $(n=122)$, spoke the mother tongue of the students.

Excerpts from the answers of mentors who spoke the mother tongue of the students:

The previous mentor told me that these students don't have learning skills, and have many learning difficulties.

When I started working with them I discovered that they have learning skills, but they have a hard time 
expressing themselves in the new language, but they are able to handle the tasks well when I explain the task to them in their mother tongue.

They understand me well and therefore have a higher motivation.

It contributes to my personal relationship with them, we feel more comfortable.

It is easier to communicate with them, to work with them, to provide information to them, as we can explain to each other what is not clear or what the difficulties are.

If they don't understand a particular word, I immediately explain it to them. I manage to communicate and talk with the really recent new immigrants, where their teachers don't succeed.

I can understand what they are telling me and can answer, and have a conversation with them in their language.

The findings showed that 33 mentors $(n=122)$ do not speak the students' mother tongue. Excerpts from the answers of mentors who do not speak the students' mother tongue:

This creates a lot of difficulty in communication because they don't know either Hebrew or English.

I extensively use translation apps, hand gestures, pantomime.

I get help from their friends who know their language and can translate for them. Lots of hand gestures, dictionary, translation apps.

It's really hard for me. Many times they prefer not to talk to me but to talk to the other mentor who speaks their language.

2. Do you feel that you are helping your students with their studies?

Yes - 112; somewhat - 10 .

Sample excerpts:

There are those who fail to learn in the regular classes because they don't understand the language and I sit with them, at their own pace, so that they understand the material.

I feel that they succeed on tests and assignments thanks to my help and thanks to their effort and hard work, which makes me feel satisfied and glad, and gives the students a sense of success and excellence. They also come and thank me all the time for my help with their studies, and the teachers also see improvement.

The grades of some of them improved a lot since I started working with them. Some of them learned a lot of new words and even wrote me thank you messages for helping them with their learning.

I have a lot of motivation to help and I feel their improvement.

3. Do you feel you are helping your students socially?

Yes - 80; somewhat - 28; no - 14.

Sample excerpts:

It's very important for me to always mediate for students who do not get along.

I don't know. This is something that is more difficult to measure. I'm kind of a "friend" for some of my students, the one who asks about and is interested in their wellbeing at school. But I don't know if I can help them socially.

I try very hard to pay attention to their social status and show them that they are not lonely.

I make sure to have personal conversations at the beginning of each lesson, and if something bothers them I take care of it.

The very fact that I'm kind of a connecting agent makes them open up.

I try very hard to help my students socially as well, because I work with them in small groups and try to engage them in a lot of educational activities and games. Beyond the fact that this way the material is more understandable, these games and activities consolidate the team and bring the students closer together.

My main job is mainly giving advice and telling stories when the students experience social difficulties and tell me. 
Each student makes different progress at the social level, but there are students who made extensive and important process.

4. Do you feel that you are helping your student emotionally?

Yes - 50; somewhat - 8 .

Sample excerpts:

I have several students who have opened up to me emotionally and really told me what they're going through and what is difficult for them. It's very important to me that they know that I'm here for them. I talk to them a lot about immigration, the situation at home, friends, and more.

We have a lot of personal conversations, it's part of the agenda that is very, very important to me, it makes me very satisfied and happy personally to see the students grow academically, socially, and emotionally.

I think that the regular individual lessons give them a sense of protection and consistency. At the lesson I don't force them to learn, I listen to what they want and feel, and act accordingly.

I try to empower all my students and give them a sense of security.

Many come to me to talk and offload what's on their mind, and when I have something to say, I say it, but even if I have nothing to say, I'm there to hear and support them, in their mother tongue, and it helps.

5. Do you think that you succeed in making it easier for your students to handle the difficulties they have as new immigrant youths?

Yes - 86; somewhat - 24; no - 12.

Sample excerpts:

I try as much as I can to bridge this huge gap, whether it's slang and phrases or whether it's organizing joint lessons of my students with students from their class who are not new immigrants.

We have a lot of personal conversations about the immigration process, difficulties, successes, and I give them a lot of tips, help with everything they need.

I think they see that there is an adult who wants to help them and believes in them, and that helps them.

I try as much as I can to help my students deal with the fact that they are young immigrants, and I do this with lessons I prepare about songs and holidays. I try to connect the students to our values and norms, and give them a sense of belonging and less foreignness and alienation.

I try very hard. Although I'm not a new immigrant who has gone through the same traumatic experience that they went through, I'm definitely trying to identify and understand as much as possible their situation, talk to them, and help them. I also help them with the tasks of daily life, such as filling forms, making appointments, etc.

6. How many hours a week, approximately, do you work with each student?

Most mentors meet with their students between 6 and 20 hours a week.

7. Do you teach them to use a computer / digital environment?

Yes - 54; somewhat - 22; no - 46.

8. Do you use a computer / digital environment to help them?

Yes - 60; somewhat - 36; no - 26.

Sample excerpts:

Games, pictures, songs, abstracts that are on the computer and for their general use.

Presentations, videos, digital books, computer games and worksheets, computerized tests, verbal and auditory translation apps, and more. 
The computer is a tool that helps me a lot in transferring the material to my students. With some of them I sit next to the computer and search for examples of language exercises and explanations, and it helps them a lot.

One of my students learns with me most of the time on a computer because she experiences the activities as fun, and in this way she's more focused and manages to learn better.

9. How do you think the computer / smartphone / digital environments help students handle their problems?

Helps - 112; somewhat - 8 .

Sample excerpts:

They have the option to translate and learn new things even when there is no professional with them; they are exposed to a lot of content and can learn in addition to what is required of them.

The technology serves as a kind of place of refuge for them, they keep in touch with friends and family abroad, get updates on events that take place in the country of origin, and so on.

The phone/computer is a place where they can communicate with each other, play, talk, laugh in phone conversations, it greatly helps them in the absorption process, especially in school.

This helps by providing more accessible information that assists in a broader understanding of the material being studied and in translation. The phone is a tool for language and extensive knowledge acquisition.

This is their world and they have more success connecting to it; there are students who like to learn in this environment.

The fact that translation is available and fast helps making conversations with the students more fluid, and digital tools often diversify the lessons - they are attractive and interactive, they attract attention.

10. The social-emotional aspects of the mentors' answers

All mentors (122) described difficulties; most of them (110) described challenges and satisfaction.

Sample excerpts:

My goal was both to connect with each one of them on a personal level and to advance them at the level of the local language. At the school where I teach there's a large number of immigrants, mainly from the former USSR and Ethiopia. Working with the new immigrants who recently immigrated to Israel is difficult and challenging, but the moments of success are most satisfying. When they come to me happy after the teacher praises them and tells them that they performed well the task on which we worked together, and when I get praise from their teachers because they see improvement in the students, for me it's a lot. Also socially I'm happy to help them and talk to them; they share with me their personal troubles. In their moments of difficulty I'm their sole listening ear. It's sad, but carries a great responsibility, always to be there for them, to find solutions, and most important, not to let them slip.

I'm constantly looking for new, creative ways to communicate even when there's no common language, when interests are different, I try to get to know and accommodate each and every student and to enter their world a little more each time.

Combine emotion and brain, always act wholeheartedly, even if you don't get feedback, know how to deal with difficulties of various kinds and how to respond to situations, know how to behave properly.

I decided to combine pictures, games, and the use of English in my lessons with some of the students, all of which made me have a much deeper connection with them, a personal and meaningful connection with my students.

This job is not simple and being all day around teenagers who don't understand a word of what I'm saying can be very frustrating. My students are very nice, some really want to learn and know, but sometimes I feel like I'm constantly in the process of trying to reach them and help them. Lots of difficulties and challenges arise, one challenge is over and a new one starts right away.

I realized that I love each and every one of my students despite the many ups and downs we experienced. I always make sure to show them that I'm here for them no matter what grade they received or what they did, and I'm happy to be that person for them and I hope they'll always have such a person in their life.

It really moves me to see how we started when they were skipping lessons or slipping away in the middle of lesson, and now we have reached the stage where they are waiting for lessons with me and turn to me when it's 
difficult for them.

\section{Discussion}

This study examined the experience of absorption of adolescents in Israel, in the digital age, through the eyes of mentors who work with them, from the mentors' social-emotional perspective of themselves and of their students. The topics are presented below in the following order: assisting students with social and emotional issues; belonging versus alienation; integrating digital environments in the mentors' work with new immigrant youths; and social-emotional aspects of the mentors' work.

Assisting students with social and emotional issues. Mentors felt that they were able to help their students (Table \# 1) deal with their social problems $(\mathrm{M}=3.9 ; 80$ mentors out of 122). Some of the mentors (80, question no. 3) stated that they worked hard to integrate their students into the social fabric and into social activities, and that this has led to an improvement of their status in class and to regular school attendance. Others (42) mentioned students' problems resulting from misunderstanding and poor communication due to difficulties with language and the pragmatic aspects of the socio-cultural context, and that as mentors, they engaged in socio-cultural mediation between the students and their classmates. Other mentors described how they observed their students, and when they saw that their students were lonely, they immediately approached them and helped them make social connections. The mentors wrote that those who sought to raise the adolescents' awareness of the new society, while observing and the new society and limiting criticism of it and the rejection of its characteristics. Mentors sought to provide their students with tools for understanding and responding to behaviors, encouraging their social involvement, as opposed to rejecting the new society.

Some of the mentors (36) noted that knowing the mother tongue of the students greatly helped advance them emotionally and socially. They noted that communicating only in the new language has led to shallowness; often the answers of the immigrant adolescents sound childish and not well suited to their age, because of their inability to conduct social-emotional discourse in the new language. For example: "It's much easier for me to help my students socially and academically when I speak their mother tongue. There is a better bond and better connection between us, much more than with the students whose mother tongue I don't speak."

It is therefore advisable to assist immigrant adolescents by arranging for them, even if only occasionally, an interaction with mentors and professionals who speak their mother tongue. The findings show that communication in the mother tongue is multi-layered and happens at the emotional and social layers, whereas communication only in the new language is liable to be technical, word translation, and such. Language is not merely a dictionary translation of a word, it is culture, idiomatic language expressions, hidden and visible meaning. A mentor who speaks the mother tongue of the students can provide significant mediation that may prevent a sense of alienation and vulnerability in the immigrant youths.

Most of the mentors (Table 1) responded that they made sure to find out why their students were absent from school, and to inquire about their wellbeing when they returned to class $(\mathrm{M}=4.3)$, to prevent their dropping out of the education system. They were able to have conversations with the students that improved their relationships and the atmosphere in the classroom $(\mathrm{M}=4.3)$. They felt confident in their ability to have a meaningful personal conversation with their students $(\mathrm{M}=4.3)$. They often found opportunities for personal conversations, and were interested in them $(M=4.2)$. Mentors were greatly concerned with what happened to their students at school $(M=4.2)$. They felt that their responses to the social problems of their students were effective and achieved their goal $(M=3.7)$. They saw the importance of having personal conversations $(\mathrm{M}=4.7)$, and made sure to conduct personal conversations with their students $(M=4.3)$. Mentors felt that they allowed time and space for dialogue with their students $(M=4.1)$. When asked if they felt that they had tools for conducting meaningful personal conversations with their students, the average response was 2.5 (28 mentors out of 122). For example, "I learned that my job is much more than teaching the new language. It is also to be a big sister, friend, authority, a source of stability and confidence for my students. I learned that being a mentor means serving as an example, that their eyes are always on me and that my actions and words have a great impact and importance. I learned that connecting emotionally is just as important as connecting intellectually, and that sometimes you have to drop everything and deal with what is happening now in the student's personal life or immediate environment. I have learned that actions are of great value, and that authority must be built through trust. I also learned how complex the lives of immigrants are, how difficult it is to break away from everything familiar and start a new page, how difficult and frustrating it is to learn a new language, what alienation is, and how important a sense of belonging is to us. I learned to accept what was different from me, and to understand that in fact we are all very similar, but perhaps most important, I learned to love so much, and that in my heart there is unlimited space."

Belonging vs. alienation. Most mentors (86 out of 122) felt that they succeeded in assisting their students in their problems as new immigrants. They stated that they managed to evoke in students a sense of belonging in the country, as 
opposed to alienation, while acknowledging the two identities of the adolescent, the original and the new. For most mentors, the emphasis was on investing in emotional, social, and academic aspects, to minimize the possible harm caused by immigration. This finding confirms reports by other studies (Birch \& Ladd, 1997, 1998; Romi et.al., 2007; Zilka, 2015, 2017), showing that as a result of migration, the wellbeing of adolescents may be impaired. Their ability to study, the process of acquiring skills, the sense of self-worth, and social connections may be impaired, which, in turn, may cause their dysfunction in various areas, and even social deviance. Therefore, most mentors sought to provide an environment for the adolescents that allowed for feelings of belonging, protection, growth, ability, meaningful interactions, positive experiences and success, which fostered a sense of self-worth, of resilience, and of contribution to the environment. For example: "I try very hard to help my students deal with the fact that they are new immigrant youths. I try to make the students connect to local norms of behavior, local culture, and give them a sense of belonging, to mitigate foreignness and alienation. Seeing my students, who six months ago didn't know how to deal with a foreign country, didn't know the language, were full of fears, anxiety, and resistance, how today they manage to communicate in the local language, knowing that I have a significant part in this success is one of the most wonderful feelings I have ever experienced."

Integrating digital environments in the work of mentors with new immigrant youths. Most mentors (112 out of 122) responded that digital environments helped adolescents in their coping. They wrote that adolescents were making extensive use of digital environments. Thanks to digital environments, especially smartphones, adolescents were able to blend into their new environment. Translation, databases, many applications, groups on social networks met their needs and helped with difficulties they encountered in real time, creating a sense of social connection and belonging. Digital environments were becoming increasingly available, with expanding functionality and a wide range of applications, enabling adolescents to access learning aids and materials anytime, anywhere. These findings are similar to those of previous studies (Moore \& McElroy, 2012; Zilka, 2017, 2019a) regarding the widespread use that new immigrant youths make of digital environments, and the benefits they derive from such use.

Mentors (38) noted that they taught youths to use digital environments, applications in computerized learning environments, etc. Some of the mentors (96) noted that they integrated the digital environments in working with their students, because these environments stimulated motivation and commitment to learning, helped illustrate the learning material and made it accessible through images, animation, simulations, videos, etc. found on the Internet. These findings reinforce those of previous studies (Choi, 2012; Foti \& Mendez, 2014; Hanafi \& Samsudin, 2012; Rossing et.al., 2012; Schugar et.al., 2013; Warschauer, 2011; Zilka, 2018a, 2018b, 2019b), showing that the integration of digital environments in the lives of adolescents leads to increased motivation and to social and educational engagement, and provides fascinating and diverse learning environments (Cohen et al., 2015; Dahlstrom, 2015; Zilka, $2019 \mathrm{~b}$ ).

Social-emotional aspects of the mentors' work. All mentors (122) described the difficulties, most (110) also wrote about challenges and satisfaction, and some (12) related self-criticism about their conduct with the new immigrants. Greenberg and Watson (2006) noted that self-criticism can be a springboard for change in areas such as taking responsibility, professionalism, perseverance, and success. But when criticism becomes self-defeating, self-condemning, a negative attitude toward oneself, judgmental, and unforgiving, self-criticism can make a person feel weakened and scared, cause anxiety and feelings of helplessness, and not lead to self-awareness, openness, development, and behavior change. One's self-awareness is likely bring about a decision to change one's behavior patterns, attitude toward oneself and toward those around, and change the management of one's behavior. Self-awareness leads to self-management and acceptance of responsibility, i.e., the ability to be aware of one's emotions, express them, feel them, dispel them, and navigate them wisely. The findings of this study are similar to those of previous ones (Chittooran, 2015; Hong, \& Choi, 2015; Husaj, 2016; Saperstein, Lilje, \& Seibert, 2015): in the process of working with adolescents the mentors must address their own emotional and social issues, demonstrate these skills in their conduct with the youths, and cultivate these abilities in their students. For example: "I'm disappointed with myself, I feel that the lessons I have prepared are not challenging enough for them, that the content is not appropriate for their age." "I have a student who doesn't want to cooperate and I have another one who came from Russia a month ago, and I can't speak Russian so I can't communicate with him." "I feel frustrated, my students are not progressing fast enough, and I don't want to be in the place where I am."

Most mentors felt satisfaction and challenge, together with the difficulties they experienced. For example, "I work with adolescents who have immigrated from Russia, Ukraine, France, Iran, Morocco, and other countries. I'm slowly learning to acknowledge the cultural differences and I'm learning them. I love my students and I build relationships gradually. It's difficult, but even the small successes are definitely satisfying."

My favorite framework is the complementary one, after school hours. Children who have immigrated from the Soviet Union are attending. I have discovered fine adolescents, with exceptional talents, who just needed someone to believe in them. 
No doubt that my students are my strength. But I'm having difficulties because of communication problems. I gained a lot of insights during this period, especially into the social-emotional side of my students, insights that game me feelings of success, satisfaction, of personal connection with the students, and we have deep and open conversations that make me know them better and connect with them.

In conclusion, the work of mentors with new immigrant youths poses many challenges. The present study shows that mentors who have succeeded in their work are those who paid attention to the social-emotional side - their own and their students'; mentors who gave their students a sense of involvement, support, a feeling that they are accepted as a whole person who wants to develop and to make good and deserving choices; mentors who seek to foster a sense of belonging and protection in their students, encourage meaningful interactions, positive experiences, successes, relationships, etc., which may create feelings of resilience, appreciation, and feedback.

\section{Research Limitations and Future Studies}

The study was based on the self-report of the mentors. No observations were carried out of the mentors' work with the students. Follow-up studies should examine self-report vs. actual work of the mentors with the students.

\section{References}

Adler, P. A., \& Adler, P. (2008). Of Rhetoric and Representation: The Four Faces of Ethnography. The Quarterly Sociological, 49(1), 1-30. https://doi.org/10.1111/j.1533-8525.2007.00104.x

Atkinson, E., \& Delamont, S. (2006). In the roiling smoke: qualitative inquiry and contested fields. International Journal of Qualitative Studies in Education, 19(6), 747-755. https://doi.org/10.1080/09518390600975974

Beauchamp, C. (2015). Reflection in teacher education: issues emerging from a review of current literature. International and Multidisciplinary Perspectives, 16(1), 123-141. https://doi.org/10.1080/14623943.2014.982525

Birch, S. H., \& Ladd, G. W. (1997). The teacher-child relationship and children's early school adjustment. Journal of School Psychology, 35, 61-79. https://doi.org/10.1016/S0022-4405(96)00029-5

Birch, S. H., \& Ladd, G. W. (1998). Children's interpersonal behaviors and teacher-child relationships. Developmental Psychology, 34, 934-946. https://doi.org/10.1037/0012-1649.34.5.934

Budría, S., Colino, A., \& Martínez de Ibarreta, C. (2018). The impact of host language proficiency on employment outcomes among immigrants in Spain. Empirica, Journal of European Economics, 1-28. https://doi.org/10.1007/s10663-018-9414-x

Chittooran, M. M. (2015). Reading and writing for critical reflective thinking. New Directions for Teaching and Learning, 143, 79-95. https://doi.org/10.1002/t1.20137

Choi, C. Q. (2012). Textbooks come alive. Scientific American, 306(4), 20-21. https://doi.org/10.1038/scientificamerican0412-20b

Choi, Y. (2008). Diversity within: Subgroup differences of youth problem behaviors among Asian Pacific Islander American adolescents. Journal of Community Psychology, 36(3), 352-370. https://doi.org/10.1002/jcop.20196

Cohen, J., Vincent, J. L., Adhikari, N. K., Machado, F. R., Angus, D. C., Calandra, T., \& Tracey, K. (2015). Sepsis: a roadmap for future research. The Lancet infectious diseases, 15(5), 581-614. https://doi.org/10.1016/S1473-3099(15)70112-X

Dahlstrom, E. (2015). ECAR Study of Undergraduate Students and Information Technology. ECAR. Research report. Louisville, CO: ECAR, December.

Daloz, A. L. (1987). Effective Teaching and Mentoring. San Francisco and London: Jossey Bass Publishers.

Farr, F. (2010). The discourse of teaching practice feedback: A corpus-based investigation of spoken and written modes. London: Routledge. https://doi.org/10.4324/9780203846742

Foti, M. K., \& Mendez, J. (2014). Mobile Learning: How Students Use Mobile Devices to Support Learning. Journal of Literacy and Technology, 15(3), 1535-0975.

Gikas, J., \& Grant, M. M. (2013). Mobile computing devices in higher education: Student perspectives on learning with cellphones, smartphones and social media. The Internet and Higher Education, 19, 18-26. https://doi.org/10.1016/j.iheduc.2013.06.002

Greenberg, L. S., \& Watson, J. C. (2006). Emotion-focused therapy for depression. American Psychological Association. https://doi.org/10.1037/11286-000

Hammersley, M. (2008). Questioning Qualitative Research: Critical Essays. London, UK: Sage. 
https://doi.org/10.4135/9780857024565

Hanafi, H. F., \& Samsudin, H. (2012). Mobile Learning Environment System (MLES): The Case of Android-based Learning Application on Undergraduates' Learning International. Journal of Advanced Computer Science and Applications, (IJACSA), 3(3). https://doi.org/10.14569/IJACSA.2012.030311

Hong, Y. C., \& Choi, I. (2015). Assessing reflective thinking in solving design problems: The development of a questionnaire. British Journal of Educational Technology, 46(4), 848-863. https://doi.org/10.1111/bjet.12181

Husaj, S. (2016). Social Emotional Learning (SEL). European Journal of Multidisciplinary Studies, 1(3), 168-171. https://doi.org/10.26417/ejms.v1i3.p168-171

Jan, S. R., Ullah, F., Ali, H., \& Khan, F. (2016). Enhanced and Effective Learning through Mobile Learning: An Insight into Students Perception of Mobile Learning at University Level. International Journal of Scientific Research in Science, Engineering and Technology, 2(2), 674-681.

Johnson, L., Smith, R., Willis, H., Levine, A., \& Haywood, K. (2011). The 2011 Horizon Report. Austin, TX: The New Media Consortium.

Kagan, R. (1982). The Evolving Self: Problems and Process in Human Development. Cambridge, Mass. Harvard University Press.

Liu, K. (2015). Critical reflection as a framework for transformative learning in teacher education. Educational Review, 67(2), 135-157. https://doi.org/10.1080/00131911.2013.839546

Maldonado-Molina, M., Reingle, J. M., Wesley, G., Jennings, W. G., \& Prado, G. (2011). Drinking and driving among immigrant and US-born Hispanic young adults: Results from a longitudinal and nationally representative study. Addictive Behaviors, 36(4), 381-388. https://doi.org/10.1016/j.addbeh.2010.12.017

McCarty, T. L. (2018). Comparing 'new speakerhood': context, positionality, and power in the new sociolinguistic order. Journal of Multilingual and Multicultural Development, 39(5), 470-474 https://doi.org/10.1080/01434632.2018.1429457

Moore, K., \& McElroy, J. C. (2012). The influence of personality on Facebook usage, wall postings, and regret. Computers in Human Behavior, 28, 267-274. https://doi.org/10.1016/j.chb.2011.09.009

Nesterko, N., Ulitsa, N. \& Friedrich, M. (2018). Do They Feel the Same Way? Health-Related Quality of Life and Satisfaction with Life in Jewish Immigrants from the Former Soviet Union in Germany and Israel. Journal of Cross-Cultural Psychology, 49(4), 618-634. https://doi.org/10.1177/0022022118759223

Nooreiny, M. (2007). Telling his or her story through reflective journals. International Education Journal, 8(1), 205-220.

Puigdevall, M., Walsh, J., Amorrortu, E., \& Ortega, A. (2018). 'I'll be one of them': linguistic modes and new speakers in three minority language contexts. Journal of Multilingual and Multicultural Development, 39(5), 445-457. https://doi.org/10.1080/01434632.2018.1429453

Repke, L., \& Benet-Martínez, V. (2018). The (Diverse) Company You Keep: Content and Structure of Immigrants' Social Networks as a Window Into Intercultural Relations in Catalonia. Journal of Cross-Cultural Psychology, 49(6), 924-944. https://doi.org/10.1177/0022022117733475

Romi, S., Savicki, V., Grupper, E., \& Caspi, R. (2007). Occupational burnout among child welfare workers: A work-setting comparison. International Journal of Child and Family Welfare, 10(3-4), 93-109.

Rossing, J. P., Miller, W, Cecil, A. K., \& Stamper, S. E. (2012). iLearning: the future of higher education? Student's perceptions on learning with mobile tablets. Journal of Scholarship of Teaching and Learning, 12(2), 1-26. Retrieved from http://josotl.indiana.edu/ article/view/2023/1985

Rossiter, M. J., \& Rossiter, K. R. (2009). Immigrant youth and crime: Stakeholder perspectives on risk and protective factors. Working Paper No. WP02-09.

Saperstein, A. K., Lilje, T., \& Seibert, D. (2015). A model for teaching reflective practice. Military Medicine, 180(4), 142-146. http://militarymedicine.amsus.org/doi/pdf/10.7205/MILMED-D-14-00589

Schugar, H. R., Smith, C. A., \& Schugar, J. T. (2013). Teaching with interactive picture Ebooks in grades K- 6. Reading Teacher, 66(8), 615-624. https://doi.org/10.1002/trtr.1168

Sevinç, Y., \& Dewaele, J. M. (2018). Heritage language anxiety and majority language anxiety among Turkish immigrants in the Netherlands. International Journal of Bilingualism, August 05, 2016. https://doi.org/10.1177/1367006916661635 
Shoffner, M. (2009). The Place of the Personal: Exploring the Affective Domain through Reflection in Teacher Preparation. Teaching and Teacher Education: An International Journal of Research and Studies, 25(6), 783-789. https://doi.org/10.1016/j.tate.2008.11.012

Spallek, J., Zeeb, H., \& Razum, O. (2010). Prevention among immigrants: the example of Germany. BMC Public Health, 10, 92. https://doi.org/10.1186/1471-2458-10-92

Spörlein, C., \& Kristen, C. (2018). Educational Selectivity and Language Acquisition among Recently Arrived Immigrants. International Migration Review. https://doi.org/10.1177/0197918318798343

Sung, Y. T., Chang, K. E., \& Liu, T. C. (2016). The effects of integrating mobile devices with teaching and learning on students' learning performance: A meta-analysis and research synthesis. Computers and Education, 94, 252-275. https://doi.org/10.1016/j.compedu.2015.11.008

Warschauer, M. (2011). Tablet Computers in Education. Eventually Tablets will Facilitate more Personalized and Interactive Learning. Educational Technology Debate - Exploring Learning in Developing Countries. Retrieved from

http://edutechdebate.org/tablet-computers-in-education/eventually-tablets-will-facilitate-more-personalized-and-int eractive-learning/

Whitton, D., Sinclair, C., Barker, K., Nanlohy, P., \& Nosworthy, M. (2004). Learning for teaching: Teaching for learning. Southbank, Victoria: Thomson Learning.

Winnicott, D. W. (1965). The Maturational Process and the Facilitating Environment. New York: International University Press.

Yearwood, E. L., Crawford, S., Kelly, M., \& Moreno, N. (2007). Immigrant youth at-risk for disorders of mood: Recognizing complex dynamics. Archives of Psychiatric Nursing, 21(3), 62-171. https://doi.org/10.1016/j.apnu.2007.02.006

Zilka, C. G. (2015). Social competence of children at risk: Similarities and differences among the various assessors. In E. Grupper \& S. Romi (Eds.), Children and adolescents at risk in Israel: The voice of young people and issues faced by child and youth care workers, (2), 113-185. Tel Aviv, Israel: MOFET Institute (Hebrew).

Zilka, C. G. (2017). The Elements Way: Empowering parents, educators, and mentors in the age of new media. Issues in Informing Science and Information Technology, 14, 101-119. https://doi.org/10.28945/3702

Zilka, C. G. (2018a). Always with them: Smartphone use by children, adolescents, and young adults - characteristics, habits of use, sharing, and satisfaction of needs. Universal Access in the Information Society (UAIS). https://doi.org/10.1007/s10209-018-0635-3

Zilka, C. G. (2018b). Medium preferences of children and adolescents for content distributed by the media. Interchange (INCH), 49(4), 457-476. https://doi.org/10.1007/s10780-018-9337-2

Zilka, C. G. (2019a). The use of mobile technologies by immigrant adolescents in coping with the new language and with their formal studies. In A. Forkosh-Baruch, \& H. Meishar-Tal. (Eds.). Mobile technologies in educational organizations, (pp. 192-210). IGI Global, USA.

Zilka, C. G. (2019b). Teenagers connected to digital environments - what happens when they get to school? Commonalities, similarities and differences from their perspective. Education and Information Technologies, 25, 1743-1758. https://doi.org/10.1007/s10639-019-10052-y

Zilka, C. G. (2020a). Openness and development or self-criticism of preservice teachers watching videos of themselves teaching a lesson. Review of European Studies, 12(4). https://doi.org/10.5539/res.v12n4p1

Zilka, C. G. (2020b). Use of social networking applications (SNAs) by immigrant children, adolescents, and young adults International Journal of Mobile Communication, 18(3), 257-272. https://doi.org/10.1504/IJMC.2020.107099

Zorlu, A., \& Hartog, J. (2018). The Impact of Language on Socioeconomic Integration of Immigrants. IZA Discussion Paper No. 11485. Available at SSRN: https://ssrn.com/abstract=3170274

\section{Copyrights}

Copyright for this article is retained by the author(s), with first publication rights granted to the journal.

This is an open-access article distributed under the terms and conditions of the Creative Commons Attribution license (http://creativecommons.org/licenses/by/4.0/). 